Jurnal Teknologi Kedirgantaraan, Vol, VI No. 2, Agustus 2021, P-ISSN 2528-2778, E-ISSN 2684-9704

https://doi.org/10.35894/jtk.v6i2

\title{
Sistem Propulsi Roket Padat Untuk Rudal Anti Tank
}

\author{
Erna Shevilia Agustian \\ Prodi Teknik Penerbangan, Fakultas Teknologi Kedirgantaraan, \\ Universitas Dirgantara Marsekal Suryadarma \\ Komplek Bandara Halim Perdanakusuma, Jakarta, Indonesia \\ Corresponding Author: erna_shevilia@yahoo.co.id
}

\begin{abstract}
Abstrak - Indonesia membutuhkan ketersediaan alat peralatan pertahanan dan keamanan (Alpalhankam). Namun hal ini belum didukung oleh kemampuan industri pertahanan secara optimal, sehingga menyebabkan ketergantungan terhadap produk Alpalhankam dari luar negeri. Dengan demikian perlu adanya upaya untuk dapat menguasai teknologi, sehingga kebutuhan terhadap Alpalhankam dapat terpenuhi oleh industri dalam negeri. Indonesia menggunakan Taktik gerilya yang dalam Implementasinya menggunakan senjata-senjata yang dapat menghancurkan Alat utama Sistem Persenjataan (Alutsista) musuh yang masuk ke Indonesia seperti Tank Musuh. Berkaitan dengan hal tersebut, diperlukan suatu senjata ringan dan senjata Penghancur Tank. Anti Tank Guided Missile (ATGM) memiliki kemampuan untuk menghancurkan Tank tempur utama yang kuat dari jarak yang sangat jauh. Secara umum kinerja rudal sebagian besar bergantung pada sistem propulsinya. Sistem propulsi roket padat pada rudal digunakan terutama pada saat memerlukan percepatan yang besar, misalnya meningkatkan kecepatan tinggi dalam waktu singkat sehingga cocok diterapkan pada rudal Anti Tank. Selain itu motor roket padat juga memiliki tingkat keselamatan, keandalan, kesederhanaan desain, serta masa penyimpanan yang baik, sehingga sering digunakan dalam aplikasi militer.
\end{abstract}

Kata kunci: Alpalhankam, Alutsista, Rudal, Propulsi, Roket Padat, 


\section{PENDAHULUAN}

\subsection{Latar Belakang}

Indonesia diharapkan mampu untuk dapat memproduksi Alutsistanya sendiri, hal ini juga telah disebutkan di dalam Undang - Undang No.16 Tahun $2012^{(1)}$ bahwa untuk melindungi segenap bangsa Indonesia dan seluruh tumpah darah Indonesia, serta untuk mempertahankan kedaulatan negara dan keutuhan wilayah Negara Kesatuan Republik Indonesia, pertahanan dan keamanan negara dilaksanakan melalui sistem pertahanan dan keamanan negara yang membutuhkan ketersediaan alat peralatan pertahanan dan keamanan serta didukung oleh kemampuan industri pertahanan dalam negeri yang mandiri untuk mencapai tujuan nasional. Selain itu disebutkan pula dalam UndangUndang No.16 Tahun 2012 bahwa ketersediaan alat peralatan pertahanan dan keamanan selama ini belum didukung oleh kemampuan industri pertahanan secara optimal sehingga menyebabkan ketergantungan terhadap produk alat peralatan pertahanan dan keamanan dari luar negeri.

Terkait penguasaan teknologi, Undang-Undang No.16 Tahun 2012 tentang industri pertahanan pasal 28 ayat 1 dan 2 menjelaskan bahwa:

1. Peningkatan kemampuan dan penguasaan teknologi Industri Pertahanan dilakukan melalui penelitian dan pengembangan serta perekayasaan dalam suatu sistem nasional.

2. Pelaksana penelitian dan pengembangan serta perekayasaan sebagaimana dimaksud pada ayat (1) terdiri atas unsur:

a. lembaga penelitian dan pengembangan;

b. perguruan tinggi; c. institusi penelitian dan pengembangan, baik lembaga pemerintah maupun swasta nasional di bidang pertahanan dan keamanan;

d. pengguna; dan

e. industri alat utama.

Ninok Leksono(2), seorang analis pertahanan pernah menyebutkan bahwa "Sejauh Manusia terus dihadapkan pada kemungkinan perang, maka senjata akan tetap dibuat, dimutakhirkan dan digunakan. Baik untuk pengancaman maupun untuk peperangan". Berdasarkan buku Pokok Gerilya oleh Jenderal A.H Nasution disebutkan bahwa taktik yang digunakan di Indonesia adalah menggunakan Taktik gerilya. Dalam Implementasinya menggunakan senjata-senjata yang dapat menghancurkan alutsista musuh yang masuk ke negara Indonesia seperti Tank Musuh. Berkaitan dengan hal tersebut, diperlukan suatu senjata ringan dan senjata Penghancur Tank ${ }^{(3)}$.

Dengan diperkenalkannya Anti Tank Guided Missile (ATGM) lebih kecil yang mampu membawa hulu ledak yang lebih besar pada medan perang modern membuat infanteri memiliki kemampuan untuk menghancurkan Tank tempur utama yang kuat dari jarak yang sangat jauh, dan biasanya pada tembakan pertama $^{(4)}$.

Secara umum, kinerja rudal sebagian besar bergantung pada sistem propulsinya. Untuk kebutuhan rudal tertentu, yaitu jangkauan, kecepatan, ketinggian jelajah, dan lain sebagainya diperlukan sistem propulsi yang dirancang khusus. Jangkauan, kecepatan dan lintasan secara langsung berkaitan dengan Impuls total dari sistem propulsi. Dengan kata lain, akurasi untuk mengikuti lintasan balistik yang diprediksi merupakan fungsi dari tingkat dorongan 
dan waktu pembakaran yang sebenarnya ${ }^{(5)}$.

Secara teoritis penelitian ini diharapkan dapat menambah wawasan. Penelitian ini akan membahas konsep awal mengenai sistem propulsi yang dapat diterapkan pada rudal Anti Tank yang nantinya bisa terus dikembangkan, sehingga akhirnya dapat dihasilkan suatu produk rudal Anti Tank dengan kinerja propulsi yang sesuai dengan harapan. Penelitian ini juga merupakan suatu bentuk dukungan terhadap kemandirian produksi alutsista dalam negeri.

\section{METODE PENELITIAN}

Metode penelitian yang digunakan dalam penelitian ini adalah penelitian kualitatif dengan melakukan kajian studi literatur berupa hasil penelitian terdahulu, artikel serta referensi buku yang berkaitan dengan sistem propulsi dan rudal Anti Tank sebagai sumber data.

\section{HASIL DAN PEMBAHASAN}

\subsection{Peluru Kendali (Rudal)}

Rudal atau peluru kendali adalah senjata yang dihantarkan menuju sasaran melalui proses penerbangan. Untuk mendapatkan waktu mencapai sasaran yang singkat, umumnya mempunyai pendorong berbasis $\operatorname{roket}^{(6)}$. Secara umum, rudal memiliki bahan pendorong sendiri serta bertujuan untuk menimbulkan kerusakan pada target yang ditentukan.

Rudal dibuat untuk misi udara-keudara, permukaan-ke-udara, atau permukaan-ke-permukaan. Rudal berisi sistem propulsi, bagian hulu ledak, sistem pemandu, dan kontrol permukaan, meskipun rudal hypervelocity tidak menggunakan hulu ledak atau kontrol permukaan. Kemampuan panduan dari rudal memiliki perbedaan yang bervariasi, mulai dari kemampuan pemandu sendiri hingga ketergantungan penuh pada peralatan peluncuran untuk sinyal pemandu ${ }^{(7)}$.

\subsection{Rudal Anti Tank}

Anti Tank Guided Weapon (ATGW) diterapkan ke berbagai senjata, termasuk proyektil mortir terpandu, dan proyektil artileri terpandu, tetapi sebenarnya istilah yang paling umum digunakan adalah untuk mendeskripsikan peluru kendali portable dan istilah yang lebih spesifik yaitu 'Anti Tank Guided Missile' (ATGM). Senjatasenjata ini awalnya dirancang untuk menonaktifkan kendaraan lapis baja, tetapi sering digunakan terhadap target lain, seperti personel, kendaraan ringan, dan struktur yang diperkuat. Rudal yang ditembakkan oleh sistem ATGM adalah amunisi berpemandu presisi yang mampu mengubah arah selama terbang untuk menyerang target lebih tepat. Kebanyakan ATGM umumnya memiliki jarak jangkau sejauh $2000-5000 \mathrm{~m}^{(8)}$.

\subsection{Propulsi Rudal}

Karakteristik motor tergantung pada persyaratan Guidance, ancaman, dan karakteristik airframe. Disamping kriteria lain, desain rudal dan subsistem propulsi didorong oleh beberapa sifat seperti( ${ }^{(9)}$ :

1) Target

a) Lokasi: di udara, di luar angkasa, di darat atau laut

b) Kinematika target: Diam, bergerak lambat atau cepat dalam kaitannya dengan kecepatan rudal, bermanuver berat atau tidak

c) Bertahan atau tidak

2) Warhead dan Fuse: Apakah membutuhkan benturan tinggi atau lambat atau kecepatan relative.

3) Seeker dan Navigation: Melakukan misi dengan menetapkan batas kecepatan atau tidak. Tujuan 
umumnya adalah mencapai jarak efektif maksimum terhadap target untuk dimensi rudal tertentu.

Perancangan sistem propulsi merupakan proses iteratif yang memerlukan pertimbangan alternatif sistem propulsi, subsistem propulsi alternatif, teknologi alternatif, dan perubahan ukuran sistem propulsi. Ukuran keluaran propulsi meliputi gaya dorong, impuls spesifik, dan bobot propelan/ bahan bakar dari sistem propulsi ${ }^{(10)}$. Sistem propulsi dalam rudal adalah penggerak utama, dan dalam kasus tertentu juga menentukan kontrol penerbangan. Gaya dorong adalah komponen utama dari gaya yang bekerja pada rudal. Oleh karena itu, desain dan pengembangan sistem propulsi merupakan hal yang penting. Sistem propulsi yang digunakan dalam misil yaitu roket, ramjet, scramjet, turbojet, dan turbofan.

Sistem propulsi pada rudal terbagi dalam tiga kategori dasar, yaitu(11):

f. Roket padat (Solid Rockets) menggunakan propelan padat di mana oksidator dan bahan bakar dicampur pada microlevel untuk membentuk zat padat.

g. Roket cair (Liquid Rockets) menggunakan bahan bakar cair dan pengoksidasi yang disimpan di ruang terpisah. Komponen ini disuntikkan ke ruang bakar dan dicampur.

h. Sistem pernapasan udara (AirBreathing System) seperti ramjet dan scramjet menyimpan bahan bakar di dalam kendaraan, tetapi menggunakan oksigen atmosfer untuk pembakaran. Artinya sistem ini bisa beroperasi hanya di atmosfer (ketinggian hingga $20 \mathrm{~km}$ untuk ramjet dan 20-30 $\mathrm{km}$ untuk scramjets).

Roket dapat beroperasi pada tekanan ruang bakar tinggi, hal ini memberi mereka dorongan terhadap luas penampang yang tinggi $\left(>7 \times 10^{5} \mathrm{~N} / \mathrm{m}^{2}\right)$. Roket memiliki impuls spesifik dengan konsistensi yang rendah, inilah sebabnya mengapa roket padat digunakan terutama pada saat memerlukan percepatan yang besar, misalnya meningkatkan kecepatan tinggi dalam waktu singkat.

Prinsip operasi (siklus termodinamika) dalam roket adalah sama di semua kasus. Bahan bakar dan pengoksidasi dibakar di ruang bakar dengan tekanan tinggi. Ini mengubah energi kimia menjadi energi panas, yang kemudian diubah menjadi energi kinetik yang diarahkan oleh Nozzle roket. Momentum yang digunakan adalah gas yang dikeluarkan melalui Nozzle, sehingga dapat memberikan reaksi dorong yang mendorong kendaraan (Rudal).

\subsection{Sistem Propulsi Roket Padat}

Bagian dari Propulsi Roket Padat dengan berbagai subsistem ditunjukkan pada gambar 1.1 Berbagai subsistem tersebut akan dijelaskan secara singkat sebagai berikut ${ }^{(11):}$

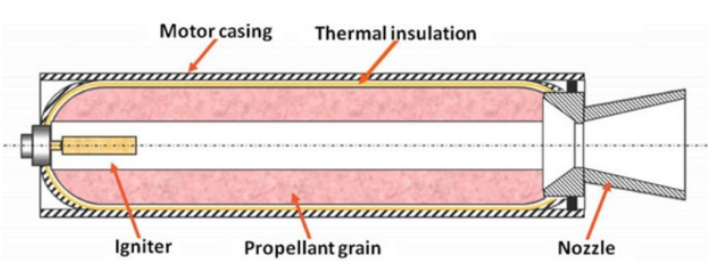

Gambar 1.1 Skema Propulsi roket padat $^{(11)}$

\section{a. Roket Motor Casing}

Fungsi utama motor roket adalah untuk memberikan impuls pendorong tertentu pada rudal dan melakukannya 
dengan berat minimum. Komponen mekanis utama terdiri dari casing motor dan Nozzle knalpot. Casing motor untuk motor roket padat berfungsi untuk:

1) Melindungi dan menyimpan butiran propelan (bentuk geometris propelan) sampai motor digunakan;

2) Sebagai ruang pembakaran (Combustion Chamber) untuk pembakaran butiran dengan tekanan dan suhu tinggi selama operasi motorik:

3) Secara mekanis/struktural berkaitan dengan komponen motor lain seperti Nozzle, igniter, internal insulation, dan penanganan/pembawa/ peluncuran Brackets;

4) Biasanya sebagai airframe utama selama penerbangan rudal, dengan demikian juga menampung control actuating system.

b. Thermal Insulation

Thermal Insulation pada motor roket adalah lapisan bahan isolasi yang ditempatkan di antara permukaan internal casing dan propelan. Profil internal isolasi memiliki ukuran yang memungkinkan propelan dapat dimasukkan secara maksimal. Tujuan utamanya adalah untuk melindungi casing motor dari lingkungan termal produk pembakaran.

\section{c. Nozzle}

Nozzle pada motor roket padat adalah bagian belakang motor yang secara hatihati mengontrol perluasan produk knalpot sehingga energi yang dihasilkan di ruang bakar secara efisien diubah menjadi daya dorong. Desain Nozzle adalah sebuah iteratif proses dimana pertimbangan aerodinamis, termodinamika, struktural dan fabrikasi direkayasa dalam batasan yang diberlakukan oleh konfigurasi Nozzle yang diperlukan.

\section{d. Igniter}

Fungsi dari igniter adalah untuk menginduksi pembakaran pada propelan secara terkontrol dengan cara yang bisa diprediksi. Konstituen dari sebagian besar penyala roket padat adalah sistem inisiasi, bahan energik berupa butiran atau pelet, dan perangkat keras serta komponen lain yang menampungnya dan menyediakan untuk pemasangan igniter ke motor roket.

e. e. Desain Butiran (Bentuk Geometris Propelan)

Tujuan utama dari desain butiran propelan padat adalah untuk mewujudkan bentuk geometris propelan yang akan menghasilkan kurva dorong versus waktu yang diperlukan dalam misi dan juga menjelaskan kendala tertentu lainnya. Desain butiran juga tergantung pada desain komponen motor lainnya. Ukuran dan batasan berat (Panjang, diameter, volume ruang yang tersedia untuk propelan, panjang nozzel, dan diameter keluar) menentukan desain parameter geometris motor.

Rudal Anti Tank memiliki motor dua tahap. Motor pertama disebut soft launch, menghasilkan gaya dorong yang cukup untuk meluncurkan tabung rudal dengan jarak yang aman, tetapi benarbenar terbakar sebelum nozzle meninggalkan tabung dan exhaust tidak mengenai operator. Setelah itu dilanjutkan dengan motor penerbangan (Tahap kedua) yang akan menyala dan membuat ATGM bergerak di sepanjang jalur serangannya ${ }^{(12)}$. Adapun motor yang dibahas disini mengenai motor dan gaya dorong pada tahap pertama yang dapat menggunakan propelan padat.

\subsection{Propelan Padat}

Propelan adalah bahan yang mudah terbakar yang didalamnya mengandung oksigen yang dibutuhkan untuk pembakaran adiabatik dan fungsi 
utamanya adalah untuk memberikan gerakan ke proyektil yaitu peluru, roket atau rudal ${ }^{(13)}$. Propelan merupakan campuran bahan kimia yang terbakar untuk menghasilkan daya dorong roket dan terdiri dari bahan bakar dan pengoksidasi. Bahan bakar adalah zat yang akan terbakar ketika dikombinasikan dengan penghasil oksigen gas untuk propulsi. Pengoksidasi adalah agen yang melepaskan oksigen untuk pembakaran dengan bahan bakar ${ }^{(14) .}$

Propelan padat maupun cair digunakan untuk eksplorasi ruang angkasa dan aplikasi militer. Namun, dari sudut pandang keselamatan, keandalan, kesederhanaan dan panjang masa penyimpanan, propelan padat lebih disukai daripada propelan cair(13).

Naumann dalam penelitiannya yang membahas mengenai Double-Pulse Solid Rocket Motor TechnologyApplications and Technical Solution ${ }^{(9)}$ juga menyebutkan beberapa alasan Motor roket padat digunakan dalam aplikasi militer dan sipil, yaitu:

a) Kesederhanaan dalam desain:

b) Penanganan yang mudah

c) Dimensi kompak

d) Potensi untuk memberikan Thrust Density yang sangat tinggi

Disampaikan oleh korotkikh et al bahwa karakteristik energi utama dari propelan roket padat adalah impuls spesifik yang signifikan dengan gaya dorong roket, dan lamanya waktu pembakaran massa propelan ${ }^{(14)}$.

Propelan padat yang umumnya digunakan untuk roket dan rudal secara luas diklasifikasikan menjadi (13):

a. Propelan homogen atau koloid

1) Single-Base Propellants

2) Double-Base Propellants:

3) Triple-Base Propellants: b. Propelan Heterogen

1) Propelan Komposit

2) Composite Modified Double Base Propellants (CMDBs)

3) Propelan kaya bahan bakar

Pada roket padat juga diperlukan desain geometri penampang propelan (Desain propelan). Beberapa desain butiran propelan yang dapat dipilih diantaranya berbentuk tubular, rod and tube, double anchor, star, multifin dan dual composition (15).

\section{KESIMPULAN}

Sistem propulsi roket padat dapat diterapkan untuk rudal Anti Tank karena memiliki beberapa keunggulan diantaranya yaitu:

a. Roket padat digunakan terutama pada saat memerlukan percepatan yang besar, misalnya meningkatkan kecepatan tinggi dalam waktu singkat.

b. Roket padat memiliki tingkat keselamatan, keandalan, kesederhanaan desain, serta masa penyimpanan yang baik.

Rudal Anti Tank memiliki motor dua tahap. Motor pertama disebut soft launch, menghasilkan gaya dorong yang cukup untuk meluncurkan tabung rudal dengan jarak yang aman. Motor dan gaya dorong pada tahap pertama inilah yang dapat menggunakan propelan padat.

\section{DAFTAR PUSTAKA}

[1]. Undang-Undang Republik Indonesia Nomor 16 Tahun 2012 Tentang Industri Pertahanan

[2]. Leksono, Ninok. (2015). Perang Yang Memutakhirkan Senjata. Majalah Angkasa-Edisi Koleksi F16 Fighting Falcon, no.94, H.111

[3]. Data wawancara Pussenif 2020

[4]. www.wikipedia.org. Peluru Kendali AntiTank. Diakses 30 Juli 2020 
[5]. Herrmann, W. (1964). United States of America Patent No. 3124072.

[6]. Triharjanto, R. H., Sofyan, E., Putro, I. E., Riyadl, A., \& Mariani, L. (2007). Rancangan Awal Dan Strategi Pengembangan Rudal Jelajah Lapan. Jurnal Teknologi Dirgantara, 103-112.

[7]. Siouris, G. M. (2004). Missile Guidance and Control System. United States of America: SpringerVerlag New York, Inc.

[8]. Berman, E. G., Jenzen-Jones, N., \& Leff, J. (2017). Anti-Tank Guided Weapons. Small Arms Survey Research Notes, 1-4.

[9]. Naumann, K., \& L. Stadler. (2010). Double-Pulse Solid Rocket Motor Technology-Applications and Technical Solutions. Aiaa/Asme/Sae/Asee Joint Propulsion Conference \& Exhibit.

[10]. Fleeman, E. L. (2001). Tactical Missile Design. United States of America: American Institute of Aeronautics and Astronautics, Inc.

[11]. Prasad, N. E., \& Wanhill, R. (2017). Aerospace Materials and Material Technologies. Kanpur, Uttar Pradesh: Springer Science+Business Media Singapore.

[12]. Zhang, D. Q. (2012). Design and Analysis of the Two-Stage FGM148 Javelin Anti-Tank Missile

[13]. Agrawal, J. P. (2010). High Energy Materials. New Delhi, India: WILEY$\mathrm{VCH}$ Verlag $\mathrm{GmbH} \& \mathrm{Co}$. KGaA.

[14]. NRS, Muda (2020). Studi Kasus 2: Teknologi Roket Pertahanan Indonesia.

[15]. Mattingly, Jack D. (2006). Elements of Propulsion: Gas Turbines and Rockets. American Institute of
Aeronautics and Astronautics, Inc. Reston, Virginia 